\title{
Performing the common good: volunteering and ethics in non-state crime prevention in South Africa
}

\author{
Thomas G. Kirsch
}

\section{Introduction}

It is often overlooked that public debates on crime in South Africa, which have intensified and have become increasingly politicized since the end of apartheid in the mid-1990s, have a strong ethical dimension. What is striking about these debates is not only that they are part and parcel of ongoing processes of postapartheid nation building, but also that they are enmeshed in a hyper-inflated field of identity politics in which heterogeneous groups of social actors struggle for public recognition of their respective claims to identity. With regard to crime prevention, this leads to a situation in which the issues of what should be the socially encompassing 'common good' in the country and the means to achieve it have become highly controversial. In addition - and like the situation in other countries in Africa, as well as worldwide - debates on crime in presentday South Africa often revolve around the different roles of state and non-state agencies in controlling and preventing crime. What is at issue here is the state's monopoly of the legitimate use of force, the capacity of post-apartheid governments to deal successfully with one of the most pressing social problems, and the promises and predicaments of the neoliberal 'responsibilization' (Rose 1999) of citizens and non-state agencies in addressing the problem of crime.

In this article, I contribute to work on non-state crime prevention in South Africa (Baker 2002; Buur 2005; Diphoorn 2015; Minnaar 2007; Wood and Shearing 2007; see also Abrahamsen and Williams 2011) in order to explore the discursive registers used by social actors in this field when they claim that their actions are based not on self-interest, but on an ethical commitment to the common good'. In doing so, I conceptually reframe the analysis and depart from previous studies by considering certain forms of non-state crime prevention, like neighbourhood watch groups and community policing forums, not in their relation to the state's crime prevention measures, but instead within the framework of volunteering (see also Brown and Prince 2016). I suggest that this provides interesting insights into how volunteering in this field contributes to communityand nation-building processes in present-day South Africa.

More particularly, I show how volunteers make reference to 'ordinary ethics' (Lambek 2010) when confronted with the scepticism of others with regard to their own motivations and activities. I argue that, as a result, volunteers not

\footnotetext{
Thomas G. Kirsch is Professor of Social and Cultural Anthropology at the University of Konstanz. He has published two books on African Christianity in Zambia and articles in some of the major refereed anthropology journals. Since 2003, he has conducted fieldwork on issues of security, crime prevention and volunteering in South Africa. Email: thomas.kirsch@uni-konstanz.de
}

(C) International African Institute 2017 
only self-identify as subjects holding pro-social ethical attitudes, but also have recourse to argumentative strategies through which the objects of ethics in the wider society are discursively framed in particular ways (see also Bochow, this issue), thus reconfiguring the ethical field in order to endow their own actions with legitimacy. My analysis below focuses on three such strategies. One of them consists in volunteers performing acts of discursive encompassment through which certain collectivities of other people, such as 'the community', 'the nation', 'society' or even 'humanity', are said to be the objects of their (self-proclaimed) ethical activities. I propose that, in this way, volunteering in the field of crime prevention contributes to discursively bringing forth these collectivities as relevant fields of collectively held ethics. ${ }^{1}$ Secondly, in cases where volunteers were reproached for being exclusivist because their activities concentrated on helping only a specific social group and not others, such as street children, the volunteers presented themselves as being motivated by abstract, socially overarching objectives, such as 'reconciliation', 'democracy' and 'peace'. As a result, they more or less indirectly promoted certain ethical principles on which they felt that human coexistence should be based universally. Last but not least, when accused of actually pursuing selfish interests, crime prevention volunteers had recourse to the idea that their personal safety represents an essential requirement for their ability to help others to keep safe as well. Interestingly, in this argumentative strategy, ethical aims were embedded in what were presented as value-free and purely instrumental premises following a logic of the ends justifying the means.

My analysis culminates in the counterintuitive finding that scholarship should not interpret people's lack of trust regarding the volunteers' work in terms of the potentially disintegrative social effects brought about by contestations over the volunteers' claims to be pursuing 'the common good'. Instead, the mistrust voiced against volunteers in the field of South African non-state crime prevention actively contributes to the constitution of 'imagined communities' (Anderson 2006) and ethical fields of different types. In other words, it is through explicit challenges concerning the volunteers' ethical commitment to 'the common good' that specific claims to represent and act in the interests of 'the common good' are being made.

In what follows, I first use an ethnographic vignette from my fieldwork as an empirical example to outline some of the social complexities involved in volunteering in South Africa. In the next section, I remark more generally on volunteering in South Africa and introduce conceptual considerations that prove helpful in the subsequent analysis. Finally, having discussed different varieties of volunteering in non-state crime prevention in South Africa, and drawing on my fieldwork data, some particularities of volunteering in this field are highlighted in order to explore the ethical claims and argumentative strategies that volunteers in South Africa's Eastern Cape Province use to counter others' scepticism about their activities. $^{2}$

\footnotetext{
${ }^{1}$ For a similar approach, see Chipkin (2007).

${ }^{2}$ Fieldwork on non-state crime prevention was conducted between 2003 and 2008 in South Africa's Eastern Cape Province, especially in the town of East London and the township of Mdantsane.
} 


\section{The social life of volunteering}

Some years ago, when conducting ethnographic fieldwork on non-state crime prevention in South Africa, I paid a visit to a day-care centre for young children in a village some miles outside the city of East London in South Africa's Eastern Cape Province. The purpose of my visit was to explore how children were trained to protect themselves socio-psychologically from becoming victims of crime by developing what the childcare workers in the centre called a 'healthy suspicion' of others.

When talking to one of the childcare workers, my attention was drawn to some intriguing aspects of the connection between volunteering and ethics. The woman, herself a white middle-class volunteer who was one of the founders of the day-care centre, told me that the relationship between the centre and the residents of the informal settlement nearby was not always easy, partly because many of the residents were eager to volunteer in the centre. These people were poor and desperate, she explained to me, and if they were allowed to volunteer, they would in all likelihood one day ask for employment, or at least to be compensated financially for their time and commitment. According to her, this was not possible because the centre did not have enough funds and, more importantly, because volunteering was irreconcilable with the expectation of material compensation. Due to her ethical principles, therefore, she could not allow people from the informal settlement to volunteer in the centre.

Taken by surprise at this line of thought, I started to enquire into her own motivations for volunteering. She said that she gained nothing from it, apart, maybe, from the fact that her volunteering allowed her to socialize with black people and move more freely in a township than any other white person she knew. This was because the local authorities in the township had informally pointed out to her that she could feel safe within the informal settlement and on the road out of it up to the crossing leading to East London, but no further. Beyond that particular crossing, she should make sure to lock her car from the inside.

I am using this ethnographic vignette as a preface to my analysis because it highlights some of the ethical ambiguities of volunteering in present-day South Africa. The above account depicts a volunteer who makes self-proclaimed ethical decisions about who should and who should not be allowed to volunteer. This is a case where the relatively destitute economic situation of a certain group of people prevents them from being accepted as 'proper volunteers' by those who are already engaged in volunteering and whose consequent social exclusivism is instrumental in maintaining a powerful asymmetry between those who help and those who are helped. It is also a case of volunteering that involves a particular type of transaction: what is provided from the one side is educational input and time for single mothers to be able to go to work; what is provided by the other is a secure space allowing for social conviviality and thus fulfilment of the white volunteer's desire to take part in the new 'deracialized' South Africa.

I am probably not alone in thinking that there is something disquietingly unsettling about this constellation, to say the least. In this article, I explore the ethical ambiguities of volunteering as idea, discourse and practice in order to examine the argumentative strategies used by South African volunteers in the field of non-state crime prevention in order to accommodate ambiguities like those outlined in the ethnographic vignette above, and to plead honesty and ethical commitment when confronted by the scepticism of others. In this sense, this article aims to contribute to the anthropological study 
of 'ordinary ethics', which, in Michael Lambek's renowned phrase, is located 'in the conjunction or movement between explicit local pronouncements and implicit local practices and circumstances' (Lambek 2010: 7).

The vignette above is illustrative of a wider field of tensions in present-day South Africa. On the one hand, the political transition to an inclusive democracy since the end of apartheid, in combination with the neoliberal orientation of postapartheid governments (cf. Gordon 2001), has strengthened the commitment to participatory approaches and citizens' active involvement in the promotion of community and nation building, development, social welfare and security. Yet, whether citizens' involvement in these matters should be seen as a welcome democratization of socio-political responsibility or instead as a process of responsibilization, in the form of the objectionable outsourcing of what have previously been the functions of state agencies, is a controversial issue. This also has a bearing on how volunteering is being interpreted and evaluated in this context: while some regard it as a positive expression of civic engagement that supplements the activities of state agencies, others are critical of the employment of volunteers as a compensatory substitute for what they consider to be one of the principal duties of the state.

On the other hand, and most importantly for this article, what is at issue in these debates is not only how public and private contributions should be balanced when tackling wider social concerns, but also the question of what in particular these contributions should aim to achieve. Given South Africa's long and conflictridden history of racial segregation and social fragmentation, recent attempts to neutralize the legacies of this history through, for example, efforts at postapartheid nation building do not find it easy to endow visions of 'the common good' with a socially encompassing persuasive power. In other words, while citizens' involvement in the promotion of social welfare and development is, in principle, widely approved in South Africa, there is much less unanimity when it comes to spelling out what the objectives and ethical values of this commitment should be.

I suggest that this is particularly pronounced in the case of volunteers in the field of non-state crime prevention, the empirical object of study of this article. Social scientific work on voluntarism has long grappled with developing an understanding of what 'voluntariness' involves, thus problematizing the relationship between a person's motivations on the one hand, and the causes and effects of these motivations in the social sphere on the other. But it is not just academics who have argued over this issue. As the case of South Africa shows, marked ambiguities between 'the egoistic ideal of self-realization and an altruistic commitment to causes which enable one to "realize oneself" through action' (Boltanski 1999: xiv) are also characteristic of the social life of volunteering more generally. Far from being accepted automatically and without question, the volunteers' legitimation for and credibility in helping others tend to come under scrutiny from those who are being helped as well as by relevant others. This is because volunteering is about people's ideas of civic virtue, the ethics of socio-political action, and the relationship between the individual and wider social configurations.

More specifically, as I show with regard to South Africa, volunteering is a form of sociality that is characterized by ambiguities that relate to: (1) the personal identity of the volunteer; (2) asymmetries in the relationship between the donor and the recipient of volunteering; (3) questions concerning the promises and predicaments of both selflessness and self-interest; and (4) the concomitant challenge 
to determine what constitutes 'the common good'. In the context of these ambiguities, pleading honesty and ethical commitment represents a widespread discursive strategy on the part of volunteers to counter the mistrust they encounter.

At the same time, as I demonstrate in what follows, this strategy is not just reactive; it is also socially productive in specific ways. First, contentions about the social identity of the volunteer are accommodated by stressing the volunteer's commitment to abstract objectives. Secondly, contentions about powerful asymmetries between the donors and the recipients of volunteering are accommodated by invoking an encompassing sociality that includes both. Last but not least, contentions about the (alleged) self-interest of volunteers are accommodated by defining the personal benefits of volunteering not as ends in themselves but as private means to public ends.

\section{Being a volunteer in South Africa (and elsewhere)}

It is beyond the scope of this article to provide a comprehensive account of volunteer activities in South Africa, past and present. Any attempt to do so would require a concept of volunteering that can be employed across vastly divergent historical eras and socio-cultural settings. Further, it would involve acknowledging that one's analysis is always and necessarily informed by one's theoretical premises with regard to the role of self-interest and selflessness in social life. For example, for Émile Durkheim, 'Altruism is not ... an agreeable ornament to social life, but it will forever be its fundamental basis' (Durkheim 1933: 228). Obviously, if we were to adopt this perspective, our understanding of volunteering would differ from an analysis based on rational choice theories. Having said that, it might suffice to note at this point that the notion of volunteering as used in this article relies on the categorical distinction between individuals and wider social realms, as well as assuming that certain individuals show relatively more engagement to the benefit of (some section of) this wider social realm than they are socially obliged to do and than would normally be expected of them.

Given this working definition, there is evidence for a varied history of activities in South Africa that bear a familiar resemblance to what we would now call 'volunteering'. For instance, Christian churches in South Africa for many decades have been devoting much energy to religiously motivated charity work: that is, to helping others by providing them with, for example, assistance in education, health issues and livelihoods (see, for example, Comaroff and Comaroff 1991; 1997). On the other hand, as has been widely discussed by historians of the African National Congress (ANC), much of what happened in the name of and to support the anti-apartheid struggle up to the mid-1990s relied on grass-roots volunteer activities (see, for example, Kimble and Unterhalter 1982; McClintock 1991). In the same vein, many decades ago, but still remembered today, Nelson Mandela was awarded the honorary title of the 'first volunteer' or the 'volunteerin-chief' in the anti-apartheid defiance campaign of the $1950 \mathrm{~s}^{3}$

\footnotetext{
${ }^{3}$ See, for example, J. Zuma (2012) 'Lecture by the President of the ANC, President Jacob Zuma, on the occasion of celebrating the life and times of the tenth President of the ANC President Nelson Mandela, Limpopo' <http://www.anc.org.za/centenary/show.php?id=9750>, accessed 28 October 2015.
} 
Even today, South Africans exhibit a vivid interest in different kinds of volunteering. According to the latest statistical data compiled in the Volunteer Activities Survey, over a million South Africans spent nearly 400 million hours on volunteer work in the twelve months ending June 2011.4 More than half of these people engage in volunteer work on an individual basis; about one-third of them do so through an organization, mainly non-governmental organizations and religious institutions. Similarly, a study published in 2006 'demonstrates that in contemporary South Africa, service programmes are growing in range and number, fostered by the policy framework that has been put in place in the new democracy since 1994' (Perold et al. 2006: 6). The main sectors of this volunteer engagement are social development, environment, health, education and agriculture.

Keeping in mind South Africa's history of racial segregation and social fragmentation, two types of volunteering can be distinguished. On the one hand, one finds volunteer engagement that is an expression of an explicit commitment to a specific cause and that is socially exclusivist - that is, it supports one specific social group as opposed to or in contradistinction to other groups. Examples of this form of volunteering include volunteer activities in the context of the anti-apartheid struggle, but also, and more recently, Jacob Zuma's political mobilization of ANC members prior to the elections of May 2014, which was framed as a re-launch of the 'volunteer brigades' (cf. Lodge 2004).

On the other hand, there is volunteering as an inclusivist and socially encompassing form of ethical engagement that aims to build a unified society by overcoming previous divisions within the bounds of the nation state. For instance, comparing present-day volunteers with anti-apartheid freedom fighters, namely the Young Lions, former South African president Thabo Mbeki advocated this generalized form of ethical commitment through volunteering at an address on the Youth Day in June 2008:

I am convinced that the young people of 2008 are as much Young Lions as were the youth of 1976, whom Oliver Tambo was inspired to describe as Young Lions. The youth of 1976 earned this honoured title ... because of what they did to contribute to the liberation of the nation from apartheid ... [Nowadays] the good role models among us, the best Young Lions, must be those who work with the community, who help the poor, who volunteer to help improve their neighbourhoods. ${ }^{5}$

Such calls for a socially encompassing approach to volunteering have been made time and again in post-apartheid South Africa. Yet, they do not merely reflect nation-building endeavours in the country but are also intricately connected to global processes which consequently have to be taken into account when looking at the South African situation. For example, opposition to the privatization of urban service delivery by volunteer 'guerrilla technicians' of the Soweto Electricity Crisis Committee (see Kirsch 2005) is internationally linked to other leftist movements opposed to neoliberalism and globalization. This is exemplified by the fact that, in a volume entitled A Movement of Movements (Mertes 2004),

\footnotetext{
${ }^{4}$ Data produced by Statistics South Africa, Pretoria, 2010.

${ }^{5}$ T. Mbeki, 'Address of the President of South Africa, Thabo Mbeki, at the Youth Day celebrations: UWC, Cape Town, 16 June 2008' < http://www.dfa.gov.za/docs/speeches/2008/mbek0617. html>, accessed 28 October 2015.
} 
one of the Soweto Electricity Crisis Committee's most prominent protagonists, Trevor Ngwane, presents his political biography side by side with articles about the Association pour une Taxation des Transactions financières pour l'Aide aux Citoyens (ATTAC).

As has been repeatedly noted, the increasing importance of volunteering is connected to neoliberal forms of governance, deregulation, decentralization and privatization, and to what Nikolas Rose (1999) has called 'responsibilization' and 'governing through freedom'. However, as Thabo Mbeki's equation of volunteers with anti-apartheid fighters attests, it would be shortsighted if a study of volunteering in South Africa were to confine itself to the criticism that the voluntary sector has been mainstreamed into neoliberal state policies.

There is more to this topic, and this becomes discernible once we take into account the ambiguities inherent in voluntarism. This notion is, of course, a controversial and elastic term that 'embraces a vast array of quite disparate activities' (Wilson 2000: 233). Broadly speaking, it refers to work that is performed without monetary reward. As such, social scientists have considered volunteering to be part of a general cluster of helping activities, to be proactive rather than reactive, and to be a pro-social activity that is positively valued by the recipients. The term 'volunteering' is consequently often used in conjunction with terms such as caring, helping, charity, altruism and beneficence. However, there is no pure gift: gift-giving, according to Marcel Mauss, is 'apparently free and disinterested but nevertheless constrained' (2002: 4). As a consequence, for Mauss, the gesture of voluntarily giving a present is 'only a polite fiction, formalism, and social deceit, [while] really there is obligation and economic self-interest' (ibid.; see also Dilger, this issue). Similarly, as noted above, volunteering is an ambiguous form of social interaction. It functions, I argue, analogously to what Maurice Godelier has written about gift-giving: namely that it 'decreases the distance between the protagonists because it is a form of sharing, and ... increases the distance between them because one is now indebted to the other' (Godelier 1997: 12, italics added).

In what follows, I concentrate on this ambiguous operation of simultaneously decreasing and increasing the distance between social actors. Taking as an example volunteering in non-state crime prevention in South Africa's Eastern Cape Province, especially the town of East London and the township of Mdantsane, as an example of 'ordinary ethics', I look at the relationship between the donors and the recipients of volunteering in order to elucidate the discursive strategies used by volunteers when the ethical honesty and selflessness of their commitment to volunteering is questioned by others. Before coming to this analysis, a brief overview of volunteering in the field of non-state crime prevention in South Africa is in order.

\section{Volunteering in non-state crime prevention in South Africa}

This article deviates from previous research on voluntarism in South Africa in that it explores an empirical phenomenon that has been neglected thus far: voluntarism in the context of non-state crime prevention. This means that I am bringing together two fields of research that are normally treated separately. On the one hand, the familiar association of volunteering with social welfare and the common good' seems to suggest that certain sub-disciplines can claim exceptional 
competences in dealing with this subject matter, such as public health, medical anthropology, social work, and the anthropology of development and humanitarianism. On the other hand, with regard to volunteer activities in non-state crime prevention, the voluntary dimension of these practices usually remains implicit in notions such as self-justice or community policing. Furthermore, as is well known from studies of and media reports on self-defence units and neighbourhood watch groups, volunteering in the field of safety and security does not always lend itself to unequivocal and unreserved ethical approval, to say the least. Due to intolerance and violent exclusivism, many of these groups are under suspicion of belonging to what Simone Chambers and Jeffrey Kopstein (2001) have called 'bad civil society'. The title of a chapter by Sabelo Ndlovu-Gatsheni and Gwinyayi Dzinesa (2008) succinctly captures this ambiguity of volunteering in the field of security: 'One man's volunteer is another man's mercenary'.

In order to assess and contextualize the role of volunteering in this field, it is therefore necessary to consider the different forms and modalities of non-state crime prevention. ${ }^{6}$ Self-justice, vigilantism and the state-endorsed involvement of private persons in acts of policing and crime prevention have always been marked features of South African history. Given the divided society in the country, social actors voluntarily engaged in the prevention of crime in order to control and suppress other sections of the population. In other contexts this represented an expression of the struggle for autonomy and self-assertion in the face of domination by oppressive social groupings or state agencies. In general, the activities of these groups have been framed in racial, ethnic, territorial or political terms; they have come into existence among both dominant and subaltern sections of society; and they have been legitimized in a variety of mutually exclusive ways. Finally, in the history of South Africa, a large number of voluntary organizations in the field of crime prevention took recourse to self-justice for the simple reason that there was no alternative. In the early 1990s, 80 per cent of all police stations were located in the neighbourhoods of 'white' people, who, however, represented just 10 per cent of the overall population. ${ }^{7}$ In the areas officially allocated to 'black' and 'coloured' people, by contrast, police forces were hardly seen - and when they were, their actions regularly involved indiscriminate killings, humiliations and gross human rights violations (Brogden and Shearing 1993; Proudlock 1999).

This overview makes it clear that voluntary non-state policing and non-state crime prevention have long been a systematic constituent of the South African socio-political environment. In this setting, at stake are the interrelated questions of the legitimacy of the state, the legitimacy of means and ends in instituting and asserting law, and the legitimacy of actors involved in the prevention, control and sanctioning of crime. Social actors from various backgrounds all claim to establish, maintain or re-establish social order. But how, in particular, this social order is envisioned and how it should be accomplished are controversial. Among other things, this is because the different groups have widely divergent understandings of the relationship between 'common good' and 'private

\footnotetext{
${ }^{6}$ In the following, I restrict myself to non-profit civic organizations and exclude private security companies from consideration.

${ }^{7}$ S. Mufamadi, 'A programme to address violent crime including the killing of police personnel', statement by the Minister of Safety and Security, media conference, Pretoria, 22 August 1994, p. 4.
} 
benefit'. What is deemed desirable and legitimate by one group is often seen as undesirable and illegitimate by others. In addition, there are blurred boundaries between the different types of groups, so that what appears, for instance, to be a neighbourhood watch group at one point in time and from one perspective is at another time and from another perspective indistinguishable from a criminal gang (see also Kirsch 2010).

Against the backdrop of these complexities, the first post-apartheid government was confronted with a series of challenges, and especially with a society that was deeply divided, citizens who mistrusted each other, and public perceptions that the rate of crime was increasing drastically. It also had to build on a state apparatus whose legitimacy had become highly questionable under apartheid (Brogden and Shearing 1993; Cawthra 1993; Shaw 2002: 22-41), and it had to face the existence of a variety of more or less informal groupings engaged in whatever they themselves - not necessarily the state - defined as crime prevention and control (see also Cooper-Knock 2016; Gordon 2007).

Given this strained situation, post-apartheid governments in South Africa have devised and implemented policies aimed at consolidating police accountability (see also Hornberger 2011; Marks 2005) while also enhancing effectiveness in the policing and prevention of crime. An important part of these policies is the creation of interfaces between the police and local 'communities': namely community policing forums (CPFs). Being based on an organizational model that has been instituted in several countries worldwide, the establishment of CPFs in South Africa has been acclaimed for representing a shift from authoritarian and reactive forms of policing to more democratic and proactive forms (cf. Davis et al. 2003), and thus becoming an expression of and catalyst for post-apartheid transformations.

Besides such links between police reform and governmental self-legitimation, there is no doubt that the increasing formalization and institutionalization of the involvement of private individuals in acts of policing and crime prevention also need to be seen as an effect of neoliberal policies that endorse publicprivate partnerships and the outsourcing of what have previously been the functions of state agencies. Yet, what is regularly overlooked and what stands at the centre of this article is that this development not only entails a shift from the public to the private sector, but also a markedly increased significance of volunteering in the prevention of crime.

As I came to learn during my fieldwork in South Africa, this also finds expression in the fact that there now exists a great multitude of non-governmental organizations, non-profit companies, social clubs, faith-based organizations and associations of different sorts that, in one way or another, seek to contribute to crime prevention. Some of these organizations are professional, highly formalized and single-purpose bodies, such as Business Against Crime South Africa (BACSA), which describes itself as 'a non-profit Company ... [that] was established by business in 1996 in response to a request from then President Nelson Mandela who invited business to join hands with Government in the fight against crime' ${ }^{8}$ Other organizations, such as certain boxing and soccer clubs in Mdantsane township in the Eastern Cape Province, have included crime

\footnotetext{
${ }^{8}$ See $<$ http://www.bac.org.za $>$, accessed 28 October 2015.
} 
prevention as a part-time add-on to their usual portfolio of activities. Still others represent more or less informal associations of people sharing a particular profession who have decided to do something against crime and violence; in the area of my research, 'Taxis against Crime' and 'Hawkers against Crime' were two groupings of this kind. Last but not least, there exists a large number of charities and non-governmental organizations whose main objective is social work and social welfare, but which also try to make a contribution to crime prevention through, for example, taking care of street children or facilitating the social rehabilitation of offenders. What these groups have in common is, first, that they have been established as self-responsibilized initiatives by non-state actors, and secondly, that they usually rely completely or at least to a substantial extent on work input by volunteers.

\section{The ethics of volunteering against crime}

In most of the non-state organizations addressing crime prevention issues that I have studied in South Africa, there have been debates over the question of whether possibilities exist to be somehow compensated for volunteering. In a CPF in the township of Mdantsane, for example, people were aware that they would not receive monetary payments from anybody, neither from the residents in the CPF's area of responsibility, nor from the police or other state agencies. All the same, members of the CPF used public transport when travelling to meetings, and those who had employment occasionally took time off due to their involvement in community policing. At the same time, while being willing to commit energy and time to volunteering, CPF members insisted that they must not be expected to spend their own money on it.

The police forces in Mdantsane, on the other hand, knew that complaints by the CPF to the provincial Department for Safety and Liaison in Bisho would have inopportune consequences for them. Police officers were therefore eager to show good working relationships with the CPF. This involved strategies for how to deal with the volunteers' actual or anticipated complaints. Thus, members of the CPF were provided with free transport to CPF meetings and to public events concerned with civic crime prevention. In addition, as I came to realize over time, some prominent CPF members were able to make use of police cars just like taxis: a phone call, a brief explanation, and then they were picked up at a certain point and dropped off at another. In one case I observed, the CPF member made the driver, a police officer, wait for more than an hour during which time the former attended to some personal business, compensating for the police officer's idle time with a friendly chat and a soft drink.

But CPF members in Mdantsane also benefited from their commitment to volunteering in another way: they were in possession of police officers' unlisted mobile phone numbers. At first sight, this does not seem to mean a lot. However, in an area where crime is rampant and where it usually takes hours for the police to make an appearance, it had value. In the case of a local friend of mine, for example, it probably saved his life. One day, walking along a street in Mdantsane, he was attacked by a gang of youngsters but succeeded in escaping and hiding in his house. However, the gang rushed after him and started to smash down the door. Fearfully lying under his bed, he dialled one of the unlisted mobile 
phone numbers he had obtained as a member of the CPF, thus making sure that the police arrived in almost no time.

These examples show that acts of volunteering do have some benefits for those who enact them, a fact that is not only acknowledged by the police and CPF members, but also noticed by other people, such as the neighbours of my friend, who after the incident speculated suspiciously why the police had responded so quickly. Volunteers in the field of civic crime prevention therefore have to justify why they volunteer and to reassure others constantly that their volunteering is not for their own profit but - at least for the most part - for the benefit of others.

What became clear to me during fieldwork is that such attitudes of distrust towards volunteers in the field of crime prevention are the rule rather than the exception. Apart from in the volunteers' immediate social surroundings, most other people did not readily acquiesce in crime prevention measures being undertaken in their name without being asked for their consent, even if these measures were said to be community-oriented and based on voluntarism. In other words, and referring to one of the concepts developed in the introduction to this special issue, they did not acquiesce when others tried to make them the objects of their own ethical commitments. This was particularly pronounced in cases when the volunteers' activities were not directed at a particular group of (also voluntarily) participating others, such as 'endangered youth' from the neighbourhood, but when they were aimed at encompassing a wider sociality, for example when patrolling the streets.

One Friday evening in 2005, for instance, I joined a group of local CPF members on their patrol through an area of Mdantsane township that was known to be frequented by a youth gang. The gang had been mugging workers on their way home, who, at the end of every working week, had just received their weekly pay. Nothing unusual happened during this patrol until, suddenly, an elderly women stopped short in front of the group, visibly gathering up all her courage, and started to raise her voice: 'Who are you? And what do you want in this area? Don't you see that children in this area are being afraid of people like you who walk around in such an intimidating manner?' One of the more senior CPF members tried to de-escalate the situation, explaining that they were there to protect the neighbourhood. Yet the woman continued in an agitated manner, now surrounded by a growing group of curious onlookers: 'I have never seen you before! I don't even know your name. You are not from this neighbourhood. So, who are you to protect me? I don't want you to do this!'

The volunteers I interviewed were usually very hesitant to talk about encounters like these because they felt unsettled by open challenges to their claim that they were acting in the interests of 'the common good'. In situations when they were confronted with suspicion by others, they explained the necessity of and their motivation for volunteering in the field of crime prevention. But they sometimes also turned the tables by explicitly and provocatively bringing into question why this particular person was opposing their crime prevention measures, thus insinuating that the person challenging them was in fact him- or herself involved in criminal activities. Also, making reference to the ethical value of protecting the wider society and acting in the interests of 'the common good' often brought controversies about this form of volunteering to a quick end because those who had challenged the volunteers then found themselves in the difficult situation of having 
to defend their view that either this specific group of volunteers or the specific measures enacted by them were not adequate to the task.

Having shown that encounters like the one described above forced volunteers to explain their motivations for volunteering in the field of crime prevention, I now scrutinize three argumentative strategies that were used by my interlocutors to plead selflessness when confronted with the scepticism and mistrust of others.

\section{Abstract objectives}

The first strategy consisted in discursively shifting the object of volunteering from a particular group of people to an abstract objective. Garett Hardin has pointed out that altruism usually means 'selectively helping only certain people and not others' (1982: 167). And, in fact, volunteering in South Africa and elsewhere is often directed at specific groups of people, whether they are defined in terms of a broad sociological classification (children, women, refugees) or of particular social categories plus certain qualifiers (street children, women who have experienced domestic violence, refugees from other countries in sub-Saharan Africa). This selectivity implies the exclusion of other groups - a fact that, unsurprisingly, is not always appreciated. For instance, when talking to a volunteer in a civic organization in East London that addresses the links between masculinity and crime and therefore directs its attention to men rather than women, it was explained to me that this organization acts as a counterbalance to other civic organizations that, according to my male interlocutor, unfairly privilege the female side of crime. 'Since nobody supports our cause,' he said, 'we have to do it for ourselves.'

This example raises an interesting point: namely the question of who volunteers for whom. The men's group in East London was criticized by members of the general public for being an example of people volunteering in their own cause. In other words, for the non-involved people I talked to, this group's activities could not be called 'volunteering' because the donors and the recipients belonged to the same social category. Similar arguments were made in the case of women volunteering for women, and so on. But, as I came to realize in the course of my fieldwork, even in those cases where volunteers belonged to a different social category than those who were the recipients of volunteering, suspicions still arose, this time because it was assumed that the donors must have a sinister, hidden agenda.

Given these suspicions, volunteers were pressured into explaining and justifying their motivations for volunteering. One of the strategies many of them used was to prioritize aims over groups. This means that, instead of talking about particular social groups as the objects of their ethical commitment that were allegedly in need of their help, the volunteers presented themselves as being committed to abstract objectives, such as 'reconciliation', 'democracy', 'peace' and 'security'.

\section{Overarching sociality}

In order to understand the second strategy used by volunteers in accommodating the ambiguities of volunteering, it is important to remember that reciprocity consists of three elements: the obligation to give, the obligation to receive and the obligation to reciprocate. Volunteering, by contrast, is the 'giving of aid ... to those 
who cannot reciprocate it' (Gouldner 1973: 274). According to the work of Alvin Gouldner on what he calls the 'norm of beneficence', this norm 'calls upon men to aid others ... solely in terms of a need imputed to the potential recipient' (ibid.: 266). But this also implies that ' $[\mathrm{t}]$ he donor gives because of what the recipient $i$, not because of what he does. The recipient self that seeks something for nothing is therefore powerless to modify the conditions of his existence' (ibid:: 270, italics added). Gouldner concludes: 'In other words, the price of unconditional help is the helplessness and unconditional dependence of the recipient on the donor' (ibid.: 271). It is in this sense that volunteering represents a powerful way of constructing systematic social asymmetries between active and passive subjects.

In the case of the volunteer organizations I studied, awareness of this asymmetry implicitly informed interactions between the donors and the recipients of volunteering. Although the recipients usually showed gratitude towards the donors, they also entertained suspicions that the volunteers considered themselves superior. The volunteers, on the other hand, tried to sidestep these suspicions by invoking the idea of an overarching sociality that contains and places on equal terms both the donors and the recipients of volunteering. As a consequence, they invoked ideas of 'community', 'society', 'the nation', or even 'humanity', thus performing an act of social encompassment that dissolved the distinction between the subjects and objects of ethics.

\section{Means to an end}

The third and final argumentative strategy I observed during fieldwork was intended to counterbalance the fact, mentioned above, that volunteers not only do good for others, but in some ways also benefited themselves from their commitment to volunteering. Some of the benefits I have mentioned were secure spaces, free transport and knowledge of the unlisted mobile phone numbers of police officers. The strategy consisted in pointing out that these benefits were not an end in themselves, but only a necessarily private means to a public end: namely, the objective of the volunteering. It meant pointing out, for example, that one had to be safe oneself to be able to provide safety for others. Thus, in this argumentative strategy, the volunteer's personal safety was not presented as the outcome of certain practices, but as the precondition for attaining outcomes for others. When seen on a more abstract level, this strategy involved the claim that the volunteer's actions were based on functional and rational premises; its rationality was not wertrational (value-oriented rationality) but zweckrational (instrumental rationality), and therefore (allegedly) ethically neutral. In addition, this strategy involved the idea of temporality and processuality, because it suggested that the volunteer had to be a recipient today in order to be a donor tomorrow.

\section{Some thoughts in conclusion}

In this article, I have suggested that volunteering in the field of non-state crime prevention in South Africa entails various ambiguities for both the donors and the recipients of volunteering, and that these ambiguities influence the ways in which this particular ethical field is delimited in interactions between the two 
groups. I outlined three argumentative strategies used by volunteers when dealing with these ambiguities: (1) accommodating challenges to the social identity of the volunteer by stressing his or her commitment to abstract objectives; (2) accommodating contentions about the powerful asymmetries between the donors and the recipients of volunteering by invoking a sociality that includes both; and (3) accommodating complaints about the (alleged) self-interest of volunteers by defining the personal benefits achieved by volunteering not as ends in themselves but as private means to public ends.

Taken together, when considered as the movement of the ethical between explicit pronouncements and implicit practices, as proposed by Lambek (2010), the first two argumentative strategies have in common that sceptical questions concerning a person's ethics are countered by reaching for a higher level of abstraction in terms of the socio-political issues being dealt with and the groups of people who are affected by them. Ethical subjects can here be said to be co-produced with communities of ethics on different social scales. At the same time, by bringing these two elements into a temporal order, the third argumentative strategy I found among South African volunteers gives precedence to the ethical subject over the community of ethics. In this understanding, the dialectical movement characterizing the co-production of ethical subjects and communities of ethics encourages an ethical momentum to emerge from the voluntas of the acting subject. As a consequence, the need to determine how such moments of ethical voluntariness relate to the ethics of 'the common good' unfolds in infinite regress.

In addition, when relating the co-production of the ethical subject and the community of ethics to community and nation building in present-day South Africa, all three strategies can be seen as involving an encompassment in which the difference between the donors and the recipients of volunteering is mediated on a higher level of abstraction, thus conciliating the potential conflicts between them and enacting a particular version of 'the common good' - at least for a time, and until doubts about the volunteers' (purported) selflessness are raised again.

\section{References}

Abrahamsen, R. and M. C. Williams (2011) Security Beyond the State: private security in international politics. Cambridge: Cambridge University Press.

Anderson, B. (2006) Imagined Communities: reflections on the origin and spread of nationalism. New York NY: Verso.

Baker, B. (2002) 'Living with non-state policing in South Africa: the issues and dilemmas', Journal of Modern African Studies 40 (1): 29-53.

Boltanski, L. (1999) Distant Suffering: morality, media and politics. Cambridge: Cambridge University Press.

Brogden, M. and C. Shearing (1993) Policing for a New South Africa. London: Routledge.

Brown, H. and R. J. Prince (2016) Volunteer Economies: the politics and ethics of voluntary labour in Africa. Oxford: James Currey.

Buur, L. (2005) 'The sovereign outsourced: local justice and violence in Port Elizabeth' in T. Blom Hansen and F. Stepputat (eds), Sovereign Bodies: citizens, 
migrants, and states in the postcolonial world. Princeton NJ: Princeton University Press.

Cawthra, G. (1993) Policing South Africa: the South African police and the transition from apartheid. London: Zed Books.

Chambers, S. and J. Kopstein (2001) 'Bad civil society', Political Theory 29 (6): 837-65.

Chipkin, I. (2007) Do South Africans exist? Nationalism, democracy and the identity of 'the people'. Johannesburg: Wits University Press.

Comaroff, J. and J. L. Comaroff (1991) Of Revelation and Revolution. Vol. 1: Christianity, colonialism, and consciousness in South Africa. Chicago IL: University of Chicago Press.

Comaroff, J. L. and J. Comaroff (1997) Of Revelation and Revolution. Vol. 2: The dialectics of modernity on a South African border. Chicago IL: University of Chicago Press.

Cooper-Knock, S.-J. (2016) 'Behind closed gates: everyday policing in Durban, South Africa', Africa 86 (1): 98-121.

Davis, R. C., N. J. Henderson and C. Merrick (2003) 'Community policing: variations on the Western model in the developing world', Police Practice and Research 4 (3): 285-300.

Diphoorn, T. G. (2015) Twilight Policing: private security and violence in urban South Africa. Berkeley CA: University of California Press.

Durkheim, E. (1933) The Division of Labour in Society. New York NY: Macmillan.

Godelier, M. (1997) The Enigma of the Gift. Cambridge: Polity Press.

Gordon, D. R. (2001) 'Side by side: neoliberalism and crime control in postapartheid South Africa', Social Justice 28 (3): 57-67.

Gordon, R. (2007) 'Popular justice' in D. Nugent and J. Vincent (eds), $A$ Companion to the Anthropology of Politics. Oxford: Blackwell.

Gouldner, A. W. (1973) For Sociology: renewal and critique in sociology today. New York NY: Basic Books.

Hardin, G. (1982) 'Discriminating altruisms', Zygon 17 (2): 163-86.

Hornberger, J. (2011) Policing and Human Rights: the meaning of violence and justice in the everyday policing of Johannesburg. New York NY: Routledge.

Kimble, J. and E. Unterhalter (1982) "“We opened the road for you, you must go forward": ANC women's struggles, 1912-1982', Feminist Review 12: 11-35.

Kirsch, T. G. (2005) "IIllegal connections": conflicts over electricity in Soweto, South Africa', Soziale Welt 16 (special issue): 193-208.

Kirsch, T. G. (2010) 'Violence in the name of democracy: community policing, vigilante action and nation-building in South Africa' in T. G. Kirsch and T. Grätz (eds), Domesticating Vigilantism in Africa. Oxford: James Currey.

Lambek, M. (2010) 'Introduction' in M. Lambek (ed.), Ordinary Ethics: anthropology, language, and action. New York NY: Fordham University Press.

Lodge, T. (2004) 'The ANC and the development of party politics in modern South Africa', Journal of Modern African Studies 42 (2): 189-219.

Marks, M. (2005) Transforming the Robocops: changing police in South Africa. Scottsville: University of KwaZulu-Natal Press.

Mauss, M. (2002) The Gift. London: Routledge.

McClintock, A. (1991) "NNo longer in a future heaven": women and nationalism in South Africa', Transition 51: 104-23. 
Mertes, T. (2004) A Movement of Movements: is another world really possible? London: Verso.

Minnaar, A. (2007) 'Oversight and monitoring of non-state private policing: the private security practitioners in South Africa' in S. Gumedze (ed.), Private Security in Africa: manifestation, challenges and regulation. Cape Town: Institute for Security Studies.

Ndlovu-Gatsheni, S. J. and G. A. Dzinesa (2008) “'One man's volunteer is another man's mercenary?" Mapping the extent of mercenarism and its impact on human security in Africa' in S. Gumedze (ed.), Elimination of Mercenarism in Africa. Pretoria: Institute for Security Studies.

Perold, H., R. Carapinha and S. E. Mohamed (2006) Five-country Study on Service and Volunteering in Southern Africa: South Africa country report. Johannesburg: VOSESA.

Proudlock, P. (1999) 'Licence to kill: police use of force', Crime and Conflict 15: $28-32$.

Rose, N. (1999) Powers of Freedom: reframing political thought. Cambridge: Cambridge University Press.

Shaw, M. (2002) Crime and Policing in Post-apartheid South Africa: transformation under fire. Cape Town: David Philip.

Wilson, J. (2000) 'Volunteering', Annual Review of Sociology 26: 215-40.

Wood, J. and C. Shearing (2007) Imagining Security. Portland OR: Willan Publishers.

\begin{abstract}
Using fieldwork data from South Africa's Eastern Cape Province, this article highlights ambiguities of volunteering as idea and practice by exploring discursive strategies used by volunteers in the field of civic crime prevention when the ethical honesty and selflessness of their commitment to volunteering is questioned by others. These ambiguities relate to asymmetries in the relationship between donors and recipients of volunteering, as well as, most importantly, the challenge to determine what constitutes the 'common good'. This article demonstrates that these strategies entail the accommodation of contentions about: (1) the social identity of the volunteer by stressing the volunteer's commitment to abstract causes and objectives; (2) powerful asymmetries between donors and recipients of volunteering by invoking an encompassing sociality; and/or (3) the (alleged) self-interest of volunteers by defining the personal benefits achieved by volunteering not as an end in themselves but as 'private means' to 'public ends'. All three strategies have in common that volunteers as 'ethical subjects' can here be shown to be co-produced with South African 'communities of ethics' on different social scales.
\end{abstract}

\title{
Résumé
}

S'appuyant sur des travaux menés dans la province de l'Eastern Cape en Afrique du Sud, cet article met en lumière les ambiguïtés du bénévolat en tant qu'idée et pratique en explorant des stratégies discursives utilisées par des bénévoles dans le domaine de la prévention civique de la criminalité lorsque certains mettent en doute l'honnêteté et l'altruisme éthiques de leur engagement. Ces ambiguïtés sont liées aux asymétries dans la relation entre donateurs et bénéficiaires du 
bénévolat, mais aussi et surtout à la difficulté de déterminer ce qui constitue le « bien commun ». L'article démontre que ces stratégies impliquent l'accommodement de points de divergence concernant : (1) l'identité sociale du bénévole en soulignant l'engagement du bénévole pour des causes et des objectifs abstraits ; (2) de fortes asymétries entre donateurs et bénéficiaires du bénévolat en invoquant une socialité englobante ; et/ou (3) l'intérêt personnel (présumé) des bénévoles en définissant les avantages personnels qu'offre le bénévolat non pas comme une fin en soi mais comme des " moyens privés» à des " fins publiques». Ces trois stratégies ont en commun de montrer que les bénévoles, en tant que "sujets éthiques ", sont coproduits avec des « communautés d'éthique » sud-africaines à diverses échelles sociales. 